\title{
Qualitative and quantitative assessment of genetically modified soy in enteral nutrition formulas by polymerase chain reaction based methods
}

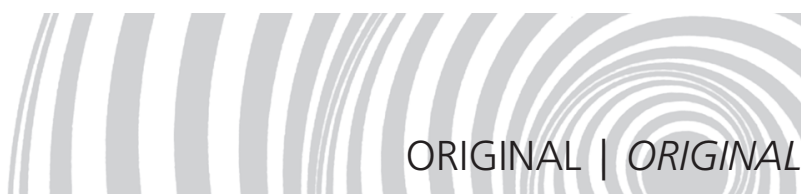

Avaliação qualitativa e quantitativa de soja geneticamente modificada em fórmulas

de nutrição enteral

Natália Eudes Fagundes de BARROS'

Edna Maria Morais OLIVEIRA ${ }^{1}$

Otniel Freitas SILVA ${ }^{1}$

Joab Trajano SILVA²

Vânia Margaret Flosi PASCHOALIN²

\section{A B S T R A C T}

\section{Objective}

The aim of this work was to investigate the occurrence of Roundup Ready soybean in enteral nutrition formulas sold in Brazil.

\section{Methods}

A duplex Polymerase Chain Reaction based on the amplification of the lectin gene and the construction of the recombinant deoxyribonucleic acid of transgenic glyphosate-tolerant soybean (355 promoter and chloroplast transit peptide gene) was performed in order to analyze the deoxyribonucleic acid obtained from nine soy protein isolate-containing formulas.

\section{Results}

Despite the highly processed nature of the food matrices, amplifiable deoxyribonucleic acid templates were obtained from all tested samples, as judged by the amplification of the lectin gene sequence. However, amplicons relative to the presence of Roundup Ready soybean were restricted to one of the nine enteral nutrition formulas analyzed as well as to the soybean reference powder, as expected. Quantitative analysis of the genetically modified formula by real-time Polymerase Chain Reaction showed a content of approximately $0.3 \%(\mathrm{w} / \mathrm{w})$ of recombinant deoxyribonucleic acid from the Roundup Ready soybean.

\footnotetext{
1 Embrapa Agroindústria de Alimentos. Av. das Américas, 29501, Guaratiba, 23020-470, Rio de Janeiro, RJ, Brasil. Correspondence to/Correspondência para: N.E.F. BARROS.E-mail: <nataliaeudes@usp.br>.

${ }^{2}$ Universidade Federal do Rio de Janeiro, Instituto de Química, Centro de Tecnologia, Departamento de Bioquímica. Rio de Janeiro, RJ, Brasil.
} 
$50 \mid$ N.E.F. BARROS et al.

\section{Conclusion}

The results show that one of the formulas contained genetically modified soy, pointing to the need of regulating the use of transgenic substances and of specific labeling in this product category.

Indexing terms: Soy protein isolate. Enteral nutrition. Organisms genetically modified. Food traceability. Polymerase chain reaction.

\section{R E S U M O}

\section{Objetivo}

Investigar a ocorrência de soja transgênica em fórmulas de suporte nutricional comercializadas no Brasil.

\section{Métodos}

Foi desenvolvido o método da reação em cadeia da polimerase duplex, com base na amplificação do gene na lectina, e na construção do ácido desoxirribonucléico recombinante da soja transgênica tolerante a glifosato (promotor $35 \mathrm{~S}$ e gene de peptídeo de trânsito de cloroplasto), a fim de avaliar o ácido desoxirribonucléico extraído a partir das nove fórmulas contendo isolado protéico de soja.

\section{Resultados}

Apesar do alto grau de processamento aos quais os produtos avaliados foram submetidos, foi possível extrair ácido desoxirribonucléico amplificável a partir de todas as amostras, demonstrado pela amplificação do gene endógeno (lectina). Adicionalmente, o fragmento relativo à modificação genética da soja transgênica foi detectado em uma das nove amostras avaliadas, bem como na amostra relativa ao material de referência contendo 1,0\% de organismo geneticamente modificado. As análises quantitativas realizadas a partir da reação em cadeia da polimerase em tempo real revelaram a presença de aproximadamente 0,3\% de ácido desoxirribonucléico recombinante derivado de organismo geneticamente modificado na amostra de fórmula que apresentou resultado positivo.

\section{Conclusão}

Os resultados demonstram que uma das fórmulas analisadas apresentava ingredientes derivados de soja geneticamente modificada, apontando para a necessidade de regulamentar a utilização de transgênicos, e de rotulagem específica nessa categoria de produtos

Termos de indexação: Isolado protéico de soja. Nutrição enteral. Organismos geneticamente modificados. Rastreabilidade alimentar. Reação em cadeia da polimerase.

\section{NTRODUCTIO N}

Soy proteins, which are known to be less allergenic than milk proteins, are used in the manufacture of many processed foods, such as infant formulas, meat extenders, baked foods, and dairy substitutes. Based on the knowledge that the consumption of soy-based products appears to reduce the risks of heart disease and cancer, the prevalence of soy proteins in food has clearly increased in the last decade ${ }^{1}$. Thus, soy protein isolate (SPI) replaces (partially or totally) calcium caseinate as the major protein source in nutritional support formulas.

Roundup Ready soybean (RRS) has been genetically modified to resist the effects of the herbicide glyphosate and has become the most prevalent transgenic crop in the world. With the introduction of Genetically Modified Organisms (GMO) into the food chain, questions on safety, gene dispersal and labeling became strongly debated among scientists and the general public ${ }^{2,3}$. In many countries, the glyphosate-tolerant soybean is approved for human consumption based on food safety assessment, which considers similar nutritional compositions ${ }^{4-6}$. There are no deleterious effects due to acute oral toxicity and presents good digestibility ${ }^{7}$. Food safety assessment practices concerning GM products assume consumption of such products by normal healthy individuals. But since the intake of these products by people with poor health has not been assessed, 
it should not be taken as completely safe. For these reasons, the presence of GMO in the formulation of healthcare products should be clearly indicated to allow a judicious analysis of possible detrimental effects of its use during long-term treatment.

Polymerase chain reaction (PCR) is the most widely used analytical method for detecting the presence of GMO in food because of its high sensitivity and reliability ${ }^{8,9}$. Multiplex PCR, a technique that simultaneously amplifies multiple target genes, will supposedly save considerable time and effort in $\mathrm{GMO}$ detection by decreasing the number of required reactions ${ }^{10,11}$.

This work investigated and quantified the presence of RRS in enteral nutrition formulas sold in Brazil using PCR-based methods: a combination of multiplex PCR and real-time PCR.

\section{METHODS}

\section{Enteral nutritional formulas and genomic DNA extraction}

Enteral nutrition formulas containing SPI as the protein source produced by three different manufacturers (named A, B and C) were purchased in local drugstores in Rio de Janeiro, Brazil, between May and June of 2006. The formulas, including powder $(n=1)$ and ready-touse $(n=8)$ preparations, are described in Table 1.
The products analyzed in this study are the most commonly used SPI-based formulas in clinical practice in Brazil. Fifty grams of each formula were homogenized by manual shaking and samples (100mg) were withdrawn for deoxyribonucleic acid extraction. Standard flours containing $<0.03,0.1$, $0.5,1.0,2.0$ and $5.0 \%$ of RRS, prepared and certified by the Institute for Reference Material and Measurement (IRMM, Geel, Belgium) were purchased from Fluka Chemika Co.

Deoxyribonucleic acid templates were prepared from $100 \mathrm{mg}$ of each nutrition formula or reference material by using the DNeasy Plant Mini Kit (Qiagen; Hilden, Germany) according to the manufacturer's instructions. DNA templates were quantified spectrophotometrically at $260 \mathrm{~nm}$ and the DNA quality was assessed by the absorption ratio at 260 and $280 \mathrm{~nm}$, which ranged from $1.8-2.0$. DNA templates were stored at $-20^{\circ} \mathrm{C}$.

\section{Qualitative PCR}

The PCR primers used ${ }^{3}$ were specific for RRS detection (Table 2), since they amplify the junction region of the recombinant DNA construct (E35S promoter and chloroplast transit peptide 4 gene). Another primer pair, SL, forward and reverse, was used to amplify the soybean lectin gene (Le1), as internal control. Both primers were purchased from Invitrogen Life Technologies (São Paulo, Brazil), in a purified and desalted form, after

Table 1. Characteristics of the analyzed enteral nutrition formulas.

\begin{tabular}{llccc}
\hline Sample & Nutrient profile & SPI $(\mathrm{g} / \mathrm{L})$ & Origin & Manufacturer \\
\hline E01 & AEC, APC, RF, Hyp & 7.80 & Canada & A \\
E02 & AEC, APC, RF, Iso & 5.94 & Canada & A \\
E03 & AEC, HP, RF, Iso & 7.09 & Canada & USA \\
E04 & AEC, HP, RF, Iso & 3.78 & Brazil & A \\
E05 & HE, HP, RF, Hyp & 6.54 & Brazil & B \\
E06 & AEC, HP, WF, Iso & 8.00 & Brazil & B \\
E07 & AEC, HP, RF, Iso & 6.52 & Holland & B \\
E08 & AEC, APC, WF, Iso & 20.00 & Argentina & C \\
E09 & AEC, APC, RF, Iso & $38.00^{*}$ & & $C$ \\
\hline
\end{tabular}

${ }^{*}$ After reconstitution of powder.

AEC: average energy content; APC: average protein content; RF: residue free; Hyp: hyperosmolar; Iso: isotonic; HP: high-protein content; HE: high-energy content; WF: with fiber. 
chromatography on reverse phase (C-18) spin column.

Amplicons generated by PCR using these primers were $125 \mathrm{bp}$ and $157 \mathrm{bp}$ in length, respectively for lectin gene and ES35 promoterchloroplast transit peptide 4 junction. Multiplex PCRs were performed in a thermal cycler GeneAmp ${ }^{\circledR}$ PCR System 2400 (PerkinElmer; Massachusetts, United States). The reaction mixtures $(50 \mu \mathrm{L}$, final volume) contained $300 \mathrm{ng}$ DNA, PCR buffer $1 \times(20 \mathrm{mM}$ Tris-HCl pH 8.4; $50 \mathrm{mM} \mathrm{KCl}), 3.5 \mathrm{mM} \mathrm{MgCl}{ }_{2}, 400 \mu \mathrm{M}$ of each dNTP (GE Healthcare; Buckinghamshire, UK), $0.15 \mathrm{U} / \mu \mathrm{L}$ recombinant Taq DNA polymerase (Invitrogen Life Technologies; São Paulo, Brazil) and primers mix $1 \times$. A primer mixture containing $0.2 \mu \mathrm{M}$ for $\mathrm{SL}$ forward and SL reverse primers; $0.4 \mu \mathrm{M}$ for RR reverse primer; and $0.6 \mu \mathrm{M}$ for P-E35S forward primer was used to reduce the analysis-to-analysis variability. Thermal cycling procedure included an initial denaturation step $\left(95^{\circ} \mathrm{C}\right.$ for $\left.5 \mathrm{~min}\right), 40$ cycles consisting of denaturation at $95^{\circ} \mathrm{C}$ for $50 \mathrm{~s}$, primer annealing at $60^{\circ} \mathrm{C}$ for 50 s, elongation at $72^{\circ} \mathrm{C}$ for $50 \mathrm{~s}$, and a final elongation period at $72^{\circ} \mathrm{C}$ for 5 min. When assembling each $P C R$, mixture reactions containing DNA templates obtained from natural soybean and from GM certified powder containing $1 \%$ RRS) or water were routinely set up. Amplified products were separated on a 2.0\% agarose gel, prepared in $1 \times$ TAE buffer stained by ethidium bromide $\left(0.5 \mu \mathrm{gmL}^{*}\right)$ and documented under UV light (302nm) with Polaroid type 665 films.

\section{Quantitative PCR}

Real-time PCR was performed in a $A B I$ Prism 7000 Detection System (Applied Biosystems,
California, United States). Considering that the only GMO present in the formulas would be from RRS, quantitative analyses were performed using the GMO Quant Roundup Ready ${ }^{\circledR}$ DNA Quantification kit (Applied Biosystems, California, United States). This assay uses specific probes to detect the $35 \mathrm{~S}$ and lectin amplicons, labeled by fluorescent dyes FAM and VIC, respectively. PCR mixture reactions $(20 \mu \mathrm{L}$ final volume) contained $20 \mathrm{mM}$ Tris- $\mathrm{Cl} \mathrm{pH} 8.0,10 \mathrm{mM} \mathrm{KCl}, 150 \mu \mathrm{g} / \mathrm{mL}$ bovine serum albumin, 60nM ROX passive reference, $5.0 \mathrm{mM} \mathrm{MgCl}_{2}, 200 \mu \mathrm{M}$ of each dNTP, $5 \mathrm{U} /$ reaction of AmpliTaq gold DNA polymerase, and 100ng of each DNA template. Thermal cycler conditions were as follows: preincubation at $95^{\circ} \mathrm{C}$ for $10 \mathrm{~min}, 40$ cycles consisting of DNA denaturation at $95^{\circ} \mathrm{C}$ for $15 \mathrm{~s}$ and primer annealing at $60^{\circ} \mathrm{C}$ for 60 s. DNA templates obtained from certified reference materials were used as positive reaction controls. All measurements were carried out in triplicate.

Average and standard deviations of delta threshold cycle $(\mathrm{Ct})$ values $\left(\mathrm{Ct}_{\mathrm{RRS}}-\mathrm{Ct}_{\mathrm{LEC}}\right)$ were calculated using the $\mathrm{GMO}$ Analysis $\mathrm{Macro}^{\mathrm{TM}} \vee \mathrm{v} 1.7$ (Applied Biosystems, California, United States). IRRM containing $<0.03 \%$; $0.1 \%$; $0.5 \%$; $1.0 \%$; $2.0 \%$ and $5.0 \%$ were used to construct the standard curves by plotting $\Delta C$ t values against $\log _{10}$ of DNA amount and fitted by linear least square regression. The RRS content of the nutrition formulas (in percent) was determined by interpolation with the standard curve of $\mathrm{Ct}$ values. All measurements were performed in triplicate.

\section{RESULTS AND DISCUSSION}

In view of the complexity of the food matrix and the technological process used in the

Table 2. Primers used in qualitative polymerase chain reaction using isolated DNA from enteral nutrition formulas.

\begin{tabular}{llll}
\hline Primer & Sequence & Specificity & Amplicon expected \\
\hline SL for & ATGGGCTTGCCTTCTTTCT & Lectin gene & $157 \mathrm{bp}$ \\
SL rev & CCGATGTGTGGATTTGGG & Lectin gene & $125 \mathrm{bp}$ \\
P-E35S for & CATTTCATTTGGAGAGGACACG & E35S promoter & chloroplast transit peptide \\
RR rev & TGGGGTTATGGAATTGGAA & 4gene & \\
& & & \\
\hline
\end{tabular}


manufacturing of enteral nutrition formulas, the DNA extracted from such samples could be damaged or fragmented or even contaminated by PCR inhibitors ${ }^{12,13}$. The DNeasy Plant Mini kit, a DNA-binding silica resin, was chosen to obtain amplifiable DNA templates from those highly processed materials ${ }^{14,15}$. Indeed, using this methodology, it was obtained amplifiable soy DNA from all samples, as confirmed by the amplification of the lectin gene sequences that produced the expected amplicon of 157bp in all duplex PCR, regardless of whether it was performed using DNA templates obtained from GM soybean reference materials or enteral nutrition formulas (Figure 1, lanes 2 to 5). On the other hand, the amplification of the 125bp fragment, exclusive to the presence of RRS (event GTS 40-3-2), was restricted to those duplex PCR reactions performed using DNA templates from the E09 sample and from reference standard GM soybean powder (Figure 1, lanes 3 and 5). The GM-positive formula (E09) was also analyzed by real-time PCR in order to quantify the amount of recombinant DNA from RRS present in this product. The critical parameters were $\mathrm{Ct}$ and delta $\mathrm{Ct}$ values $\left(\mathrm{Ct}_{\mathrm{RRS}}-\mathrm{Ct}_{\mathrm{LEC}}\right)$ and the standard curve was constructed by a semi-logarithmic linear regression analysis from $\mathrm{Ct}$ values obtained when DNA templates obtained from GM soybean reference standards containing different percentage of GM soy were analyzed as well as from their respective delta $\mathrm{Ct}$ values derived from the fluorescence signal. The percentage of recombinant DNA from RRS of each food sample was calculated using the delta Ct value from the individual sample and the parameters associated with the standard curve ${ }^{16}$. Quantitative analysis revealed the presence of approximately $0.3 \%$ of recombinant DNA in the E09 sample, with the correlation coefficient of the standard curve being 0.9943 (Table 3).

Table 3. Quantitative assessment of the Roundup Ready soybean in enteral nutrition formula E09 by real-time polymerase chain reaction.

\begin{tabular}{|c|c|c|c|c|}
\hline Sample/standard & Delta Ct & Mean delta Ct & S.D. delta Ct & $\% G M O$ \\
\hline \multirow{3}{*}{$0.1 \%$ GMO soy } & 12.48 & & & \\
\hline & 13.14 & 13.09 & 0.47 & $0.1^{*}$ \\
\hline & 13.64 & & & \\
\hline \multirow{3}{*}{$0.5 \%$ GMO soy } & 10.23 & & & \\
\hline & 10.94 & 10.87 & 0.50 & $0.5^{*}$ \\
\hline & 11.45 & & & \\
\hline \multirow{3}{*}{$1.0 \%$ GMO soy } & 9.77 & & & \\
\hline & 9.84 & 9.87 & 0.05 & $0.9^{*}$ \\
\hline & 10.10 & & & \\
\hline \multirow{3}{*}{$2.0 \% \mathrm{GMO}$ soy } & 8.75 & & & \\
\hline & 7.91 & 8.40 & 0.59 & $2.4^{*}$ \\
\hline & 8.53 & & & \\
\hline \multirow{3}{*}{$5.0 \%$ GMO soy } & 7.14 & & & \\
\hline & 7.19 & 7.29 & 0.04 & $4.9^{*}$ \\
\hline & 7.53 & & & \\
\hline \multirow{3}{*}{ E09 } & 11.70 & & & \\
\hline & 10.88 & 11.72 & 0.58 & 0.3 \\
\hline & 12.57 & & & \\
\hline
\end{tabular}

${ }^{*} r^{2}=0.9943$.

Ct: cycle of threshold; SD: standard deviation. 


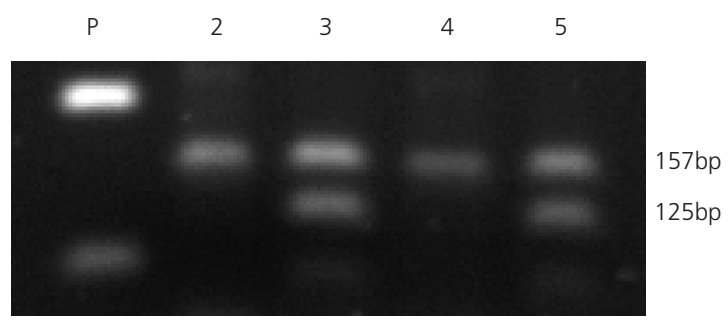

Figure 1. Duplex polymerase chain reaction detection of lectin and E35S promoter/chloroplast transit peptide 4 genes in enteral nutrition formulas.

Note: DNA templates, prepared with the DNeasy Plant Mini kit, were amplified using the primers listed in table 2. PCR products were resolved on $2.0 \%$ agarose gel stained by ethidium bromide. Lane 2: RSS free soybean powder; lane 3: soybean powder with 1\% RRS; lane 4: representative PCR amplicons from E01 to E08 formulas; lane 5: E09 formula; P - 100bp DNA ladder.

A low percentage of recombinant DNA as that found in formula E09 - 0.3\% -suggests that the amount of RRS detected would be adventitious. Low percentages of recombinant DNA from RRS were also detected in $14.7 \%$ of 200 processed soybean-based foods analyzed previously ${ }^{17}$, using a similar experimental design.

The use of GMO-derived ingredients in food products is controlled in Brazil. Regulation $11105 / 2005$ states that all foods or food ingredients, for human or animal consumption, containing more than $1 \%$ of GM ingredients should include the information about the transgenic source in the product label. Indeed, resolution 449/1999 from Agência Nacional de Vigilância Sanitária (National Health Surveillance Agency in Brazil), containing the Technical Regulation for Setting of Identity and Quality for Foods for Enteral Nutrition, did not mention GMO.

The glyphosate-tolerant soybean is approved for human consumption in many countries based on food safety assessment, which considers the similar nutritional composition ${ }^{4-6}$, no deleterious effects due to acute oral toxicity and has good digestibility ${ }^{7}$. However, toxic effects concerning GMO have been described. Significant changes in nuclear features were described in the nuclei of hepatocytes ${ }^{18}$ and in testis Sertoli cells ${ }^{19}$ in mice fed GM soybean. Moreover, significant amounts (14\%) of GM food also seem to influence zymogen synthesis and processing in mouse pancreatic acinar cells ${ }^{20}$ in parallel with a significant lowering of nucleoplasmic and nucleolar splicing factors and perichromatin granule accumulation $^{21}$. If changes in transcripcional/ translational pathways can occur, studies on the safety of GMOs for human consumption should be performed in experimental animal models before submitting it to authority assessment because the risk associated with it should be characterized to determine its relevance to human health ${ }^{22}$. However, risk assessment is carried without taking into consideration possible deleterious effects of this diet on persons with compromised health status. Additionally, some pathological processes such as cancer or neurological diseases ${ }^{23}$ could provoke several metabolic changes and/or toxic processes, so the consequence of long-term diets containing GMO, even in low concentration, on such population should be carefully assessed.

\section{ACKNOWLEDGMENTS}

The authors thank Conselho Nacional de Desenvolvimento Científico e Tecnológico, Empresa Brasileira de Pesquisa Agropecuária and Fundação Carlos Chagas Filho de Amparo à Pesquisa do Estado do Rio de Janeiro, for sponsoring the study.

\section{COLLABORATORS}

All authors participated in the development and planning of the work and in the writing and critical review of the text.

\section{RE FE R E NCES}

1. Nestle M. Allergies to transgenic foods: questions of policy. N Engl J Med. 1996; 334(4):726-8.

2. Obermeyer G, Ferreira F. Can we predict or avoid the allergenic potential of genetically modified organisms? Int Arch Allergy Immunol. 2005; 137(2):151-2. doi: 10.1159/000086313.

3. Germini A, Zanetti A, Salati C, Rossi S, Forré C, Schimid $S$, et al. Development of a seven-target 
multiplex PCR for the simultaneous detection of transgenic soybean and maize in feeds and foods. J Agric Food Chem. 2004; 52(6):3275-80. doi: 10.1021/jf035052x.

4. List GR, Orthoefer F, Taylor N, Nelsen T, Abidi SL. Characterization of phospholipids from glyphosate-tolerant soybeans. JAOCS. 1999; 76(1):57-60. doi: 10.1007/s11746-999-0047-x.

5. Taylor NB, Fuchs RL, MacDonald J, Shariff AR, Padgette SR. Compositional analysis of glyphosatetolerant soybeans treated with glyphosate. J Agric Food Chem. 1999; 47(5):4469-73. doi: 10.1021/ jf990056g.

6. Padgette SR, Taylor NB, Nida DL, Bailey MB, MacDonald J, Holden LR, et al. The composition of glyphosate-tolerant soybean seeds is equivalent to that of conventional soybeans. J Nutr. 1996; 126(3):702-16.

7. Harrison LA, Bailey MR, Naylor M, Ream J, Hammond B, Nida DL, et al. The expressed protein in glyphosate-tolerant soybean, 5-enolpyruvylshikimate -3-phosphate synthase from Agrobacterium sp. strain CP4, is rapidly digested in vitro and is not toxic to acutely gavaged mice. J Nutr. 1996;126(3):728-40.

8. Giovannini T, Concilio L. PCR Detection of genetically modified organisms: a review. Starch. 2002; 54(3); 54:321-7. doi: 10.1002/1521-379X.

9. Rodriguez-Lazaro D, Lombard B, Smith H, Rzezuka A, D'Agostinho M, Helmuth $R$, et al. Trends in analytical methodology in food safety and quality: monitoring microorganisms and genetically modified organisms. Trends Food Sci Techonol. 2007; 18(6):306-19. doi:10.1016/j.tifs.2007.01.0 09.

10. Hernández M, Rodriguez-Lázaro D, Esteve T, Prat S, Pla M. Development of melting temperaturebased SYBR Green I polymerase chain reaction methods for multiplex genetically modified organism detection. Anal Biochem. 2003; 323(1): 164-70. doi: 10.1016/j.ab.2003.07.015.

11. Markoulatos P, Siafakas N, Moncany M. Multiplex polymerase chain reaction: a practical approach. $\underline{J}$ Clin Lab Anal. 2002; 16(1):47-51. doi 10.1002/ jcla.2058.

12. Terry CF, Harris N, Parkes HC. Detection of GM crops and their derivatives: critical steps in sample preparation and extraction. J AOAC Int. 2002; 85(3):768-74.

13. Peano C, Samson MC, Palmieri L, Gulli M, Marmiroli N. Qualitative and quantitative evaluation of the genomic DNA extracted from GMO and non-GMO foodstuffs with four different extraction methods.
J Agric Food Chem. 2004; 52(6):6962-8. doi: 10.10 21/jf040008i.

14. Tengel C, Schübler P, Setzke E, Balles J, SprengerHaubels M. PCR-based detection of genetically modified soybean and maize in raw and righly processed foodstuffs. BioTechniques. 2001; 31(3): 426-9.

15. Meyer R. Development and application of DNA analytical methods for the detection of GMOs in food. Food Control. 1999; 10(2):391-9. doi: 10.10 16/S0956-7135(99)00081-X.

16. Holst-Jensen A, Ronning SB, Lovseth A, Berdal KG. $P C R$ technology for screening and quantification of genetically modified organisms (GMOs). Anal Bioanal Chem. 2003; 375(5):985-93. doi: 10.100 7/s00216-003-1767-7.

17. Greiner R, Konietzny U, Villavicencio ALCH. Qualitative and quantitative detection of genetically modified maize and soy in processed foods sold commercially in Brazil by PCR-based methods. Food Control. 2005; 16(4):753-9. doi: 10.1016/j.foodcont.2004.06.015.

18. Malatesta M, Caporaloni C, Gavaudan S, Rocchi MBL, Tiberi C, Gazzanelli G. Ultrastructural morphometrical and immunocytochemical analyses of hepatocyte nuclei from mice fed on genetically modified soybean. Cell Struct Funct. 2002a; 27(2):173-80. doi:10.1247/csf.27.173.

19. Vecchio L, Cisterna B, Malatesta M, Martin TE, Biggiogera M. Ultrastructural analysis of testes from mice fed on genetically modified soybean. Eur J Histochem. 2004; 48(4):448-54.

20. Malatesta M, Caporaloni C, Rossi L, Battlstee S, Rocchi MBL, Tonucce F, et al. Ultrastructural analysis of pancreatic acinar cells from mice fed on genetically modified soybean. J Anat. 2002B; 201(3):409-16. doi: 10.1046/j.0021-8782.20 02.00 103.x.

21. Biggiogera $M$, Manuali E, Rocchi MBL, Baldelli B, Gazzanelli $G$. Fine structural analyses of pancreatic acinar cell nuclei from mice fed on GM soybean. Eur J Histochem. 2003; 47(2):385-8.

22. World Health Organization. 20 Questions on Genetically Modified Foods. [cited 2005 Feb 27]. Available from: <http://www.who.int/foodsafety/ biotech/codex_taskforce/en/index.html>.

23. Dickerson RN, Brown RO. Long-term enteral nutrition support and the risk of dehydration. Nutr Clin Pract. 2005; 20(6):646-53. doi: 10.117701154 26505020006646.

Received on: 11/3/2008

Final version resubmitted on: 14/4/2009

Approved on: 6/10/2009 
